Aurel Nuro*, Bledar Murtaj, Elda Marku

Tirana University, Department of Chemistry, Faculty of Natural Sciences, Tirana, Albania
Scientific paper

ISSN 0351-9465, E-ISSN 2466-2585

UDC:504.5:661.16(262.3):303.433.2(496.5)

doi: $10.5937 /$ zasmat2004306N

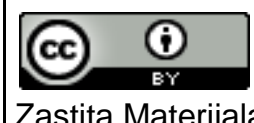

Zastita Materijala 61 (4)

$306-312$ (2020)

\title{
Levels of some organic pollutants in water samples of Adriatic Sea. case study: Hot-spot of Porto-Romano, Albania
}

\begin{abstract}
This paper presents concentrations of organochlorine pesticides (OCPs), polychlorinated biphenyls (PCBs) and polycyclic aromatic hydrocarbons (PAHs) in marine water samples of PortoRomano area. Porto-Romano is situated in Adriatic Sea, near city of Durres, in central Albania. It was considered Hot-spot area because before 90' there was located chemical plant for Lindane production. Landfill near Porto-Romano and elevated activity for industrial development of this area can be the main sources of water pollution in recent years. Water samples were taken in December 2018 and April 2019 in nine stations of Porto-Romano. Liquid-liquid extraction was used for isolate organic pollutants from water samples. Clean-up procedure for chlorinated pollutants was realized in a Florisil column. Qualitative and quantitative analyzes of pesticides and $P C B s$ were performed in HP 6890 Series II, gas chromatograph equipped with $\mu$-ECD detector. For separation of organochlorine pollutants was used Rtx-5 capillary column. Analyzes of PAH were realized in Varian 450 GC, gas chromatograph equipped with FID detector and VF-1ms capillary column.
\end{abstract}

The most frequent organic pollutants in water samples of Porto-Romano were found organochlorine pesticides because of ex-chemical plants impact in this area. Note, that Lindane and its isomers weren't found in high concentration. PCB 28, volatile congener, was found in higher concentrations because of their atmospheric origin. Presence of $P C B 138$ show terrestrial origin of PCBs in this area. PAH were found in higher concentrations inside of hydrocarbon port. Their concentrations were due to industrial activity and ship transport in this area. Mismanagement of Lindane plant wastes, urban pollution and recent industrial activity are factors of continues pollution in Porto-Romano area. Presence of organic pollutants in water samples of Porto-Romano indicates that monitoring of this Hot-spot should be continuous.

Keywords: Organochlorine pesticides; PCBs; PAH; water pollution; GC/ECD/FID.

\section{INTRODUCTION}

Porto-Romano is situated $7 \mathrm{~km}$ in North of Durres city, facing the Adriatic Sea. During communism, this area was known for the chemical plant that produced Lindane for agriculture purposes and sodium dichromate for leather tanning. Industrial wastes of this plant for many years were discharged directly to the sea. Lindane plant was abandoned after the 90' where hundreds of tons of pesticides seriously contaminated the water, soil and air near Porto-Romano [1].

\footnotetext{
${ }^{*}$ Corresponding author: Aurel Nuro

E-mail: aurel.nuro@fshn.edu.al

Paper received: 08. 07. 2020.

Paper accepted: 02. 08. 2020.

Paper is available on the website:

www.idk.org.rs/journal
}

Soil rinsing near Porto-Romano and absorbed pesticides in the sediments of this area facilitate their continuous presence in the water column. DDT, Lindane, HCB, Aldrins, Heptachlors and Endosulfanes were the most used pesticides in Albania before the 1990s. A good part of them (more than 10 tons) were deposited near Lindan factory before it completes destruction. For several years these wastes were left without proper care. Investments for clean-up of Porto Romano area started in November 2005 as part of a big World Bank-supported project on the Integrated Coastal Zone Management and Clean-up in Albania. Almost 750 tons of pesticides were repackaged in the storage site and transported to a specialized German disposal site in 2006 [1]. Pesticides with chlorine in their molecules are usually very stable compounds that can spread easy far away from their application place [2]. Even after three 
decades, organochlorine pesticides can detected in water, soil, and biota samples in contaminated areas such as Porto-Romano area [2].

Nowadays, Porto-Romano is an important area for industrial development. There is constructed the main port for fuels in Albania. In this area are installed deposits of LPG, gasoil, etc. Shipping, fuel transfer processes and their storage not far from the coast make this an area that continues to be affected by the impact of various hydrocarbons and chemicals. Recent years, near Porto-Romano, around $500 \mathrm{~m}$ from the sea is located a landfill that collects the urban wastes of several cities (Durres, Rrogozhine, Peqin, Kavaje). The waste collection in this landfill is one of the main sources of pollution that end up in the sea water of this area. It is quite problematic for the environment and residents of this area [1]. Unfortunately, Porto-Romano is strongly influenced by anthropogenic activity for a long period of time and became a Hot-spot area of Albania. Organochlorine pesticides (OCPs), polychlorinated biphenyls (PCBs) and PAHs are chemicals of great stability, whose presence in the environment is an indication of anthropogenic pollution [3-5]. PCBs were reported frequently in environmental studies in Albania because of their atmospheric deposition. Several studies have shown that these compounds exert toxic responses including immunotoxicity, teratogenicity, endocrine disruptor, etc [6-8].

\section{MATERIALS AND METHOD}

\subsection{Marine water sampling in Porto-Romano}

The sampling of water was realized for nine different stations in Porto-Romano area. Water samples were taken in two periods December 2018 and April 2019. The sampling sites are presented in Figure 1. Three glass bottles of $2.5 \mathrm{~L}$ of water were taken from each station in $1-5 \mathrm{~m}$ distance to seashore. Water samples were transported and conserved at $+4^{\circ} \mathrm{C}$ prior to analyze.

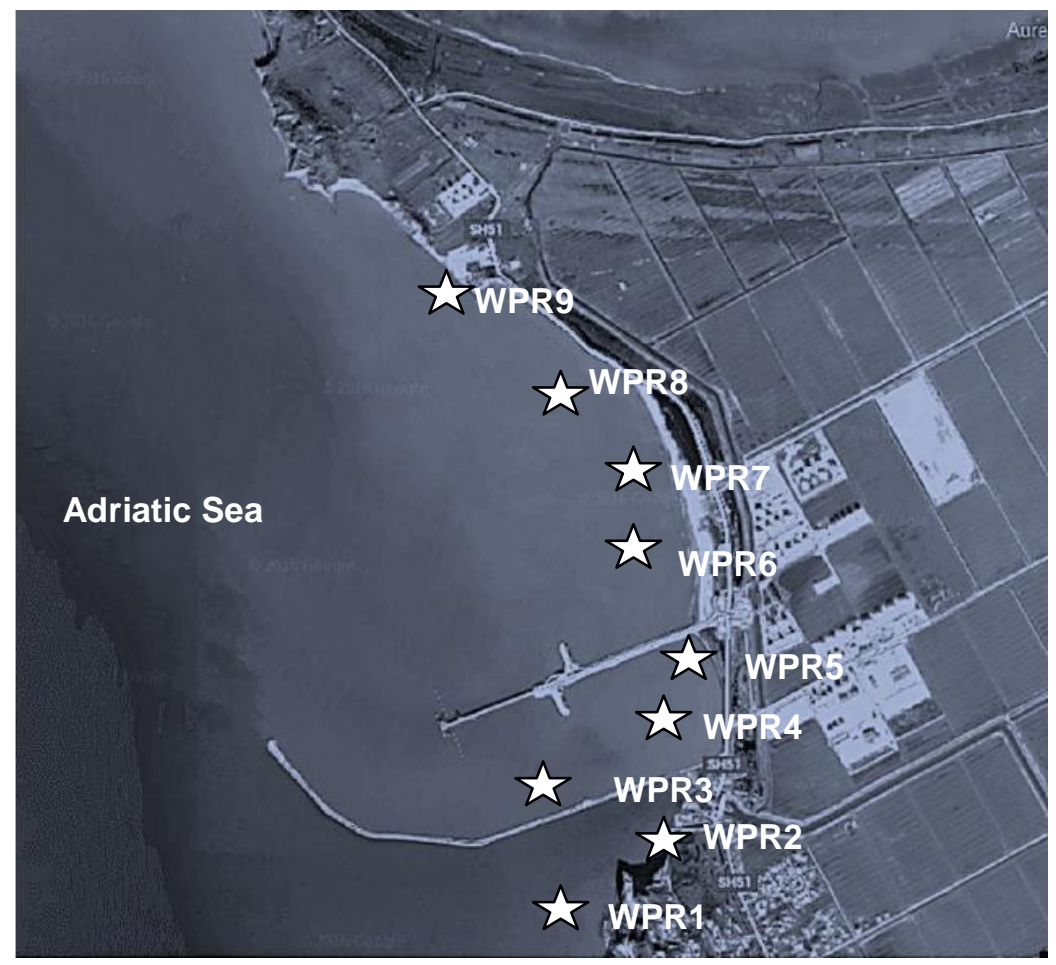

\begin{tabular}{|c|c|}
\hline Station & GPS Coordinat \\
\hline PRW1 & $\begin{array}{l}41^{\circ} 22^{\prime} 24.2^{\prime \prime} N \\
19^{\circ} 25^{\prime} 09.3^{\prime \prime} E\end{array}$ \\
\hline PRW2 & $\begin{array}{l}41^{\circ} 22 \text { '29.3"N } \\
19^{\circ} 25^{\prime} 21.1^{\prime \prime E}\end{array}$ \\
\hline PRW3 & $\begin{array}{l}41^{\circ} 22^{\prime} 39.8^{\prime \prime N} \\
19^{\circ} 25^{\prime} 10.4^{\prime \prime} \mathrm{E}\end{array}$ \\
\hline PRW4 & $\begin{array}{l}41^{\circ} 22^{\prime} 43.1^{\prime \prime} \mathrm{N} \\
19^{\circ} 25^{\prime} 22.4^{\prime \prime}\end{array}$ \\
\hline PRW5 & $\begin{array}{l}41^{\circ} 22^{\prime} 48.8^{\prime \prime N} \\
19^{\circ} 25^{\prime} 20.2^{\prime \prime} \mathrm{E}\end{array}$ \\
\hline PRW6 & $\begin{array}{l}41^{\circ} 22^{\prime} 51.5^{\prime \prime N} \\
19^{\circ} 25^{\prime} 19.3^{\prime \prime} \mathrm{E}\end{array}$ \\
\hline PRW7 & $\begin{array}{l}41^{\circ} 23^{\prime} 06.1^{\prime \prime N} \\
19^{\circ} 25^{\prime} 15.8^{\prime \prime} \mathrm{E}\end{array}$ \\
\hline PRW8 & $\begin{array}{l}41^{\circ} 23^{\prime} 15.4^{\prime \prime N} \\
19^{\circ} 25^{\prime} 09.0^{\prime \prime}\end{array}$ \\
\hline PRW9 & $\begin{array}{l}41^{\circ} 23^{\prime} 29.1^{\prime \prime} \mathrm{N} \\
19^{\circ} 24^{\prime} 45.3^{\prime \prime}\end{array}$ \\
\hline
\end{tabular}

Figure 1. Sampling map of marine water in Porto-Romano (Adriatic Sea)

Slika 1. Mapa uzorkovanja morske vode u Porto-Romanu (Jadransko more)

\subsection{Treatment of water samples for pesticide and PCB analyze}

Organochlorine pesticides and polychlorinated biphenyls were extracted simultaneously by using liquid-liquid extraction. $1 \mathrm{I}$ of water and $30 \mathrm{ml} \mathrm{n}$ - hexane as extracting solvent were added in a separator funnel. Organic phase was dried with $5 \mathrm{~g}$ anhydrous $\mathrm{Na}_{2} \mathrm{SO}_{4}$. Clean-up procedure was performed by using a Florisil column. $20 \mathrm{ml} \mathrm{n}$ Hexane/Dichloromethane (4/1) was used for their 
elution. Extract and elute were collected in Kuderna -Danish $(250 \mathrm{ml})$ to proceed their concentration in a thermal block. After that, the concentrated samples were injected in GC/ECD [7,9].

\subsection{Gas Chromatography analyzes of pesticides and PCBs}

Organochlorine pesticides (EPA 8081A) and 7 PCB markers were analyzed simultaneously by using capillary column Rtx-5, 30m long x $0.25 \mathrm{~mm}$ i.d. $x 0.25 \mu \mathrm{m}$ film thicknesses on a gas chromategraph HP 6890 Series Plus with $\mu \mathrm{ECD}$ detector. Helium was used as carrier gas and nitrogen as make-up gas. Manual injection was done in split mode $(1: 25)$ in $280^{\circ} \mathrm{C}$. The organochlorine pesticides detected were $\mathrm{HCHs}\left(a-, b-, \gamma^{-}\right.$and $\mathrm{d}$ isomers) and the DDT-related chemicals ( $p, p-D D E$, p,p-DDD and p,p-DDT), Heptachlor's, (Heptachlor, Heptachlor epoxides cis and trans isomers), Aldrines (Aldrin, Dieldrin, Endrin, Endrin aldehyde, Endrin keton), Chlordanes (alfa and gama isomers) and Endosulfanes (Endosulfan alfa, Endosulfan beta and Endosulfan sulfat). Analysis of PCBs was based on the determination of the seven PCB markers IUPAC Nr. 28, 52, 101, 118, 138, 153 and 180. Quality assurance procedures included the analyses of certified sample IAEA 435 to determine the precision and the accuracy of the method [7,911].

\subsection{Treatment of water samples for PAH analyze}

Liquid-liquid extraction was used for the extraction of polyaromatic hydrocarbons from water samples of Porto-Romano areas. $1 \mathrm{~L}$ of water and $30 \mathrm{ml}$ dichloromethane as extracting solvent were added in a separator funnel. After extraction the organic phase was dried with $5 \mathrm{~g} \mathrm{Na}_{2} \mathrm{SO}_{4}$ anhydrous for water removing. After the concentration to $1 \mathrm{ml}$, the samples were injected in GC/FID for PAH analyze [10,11].

\subsection{GC/FID determination of PAHs in water samples}

Chromatographic analyses of $13 \mathrm{PAHs}$ according EPA 525 in water samples were realized in a Varian $450 \mathrm{GC}$ instrument equipped with a flame ionization detector and PTV detector. VF-1 ms capillary column $(30 \mathrm{~m} \times 0.33 \mathrm{~mm} \times 0.25 \mu \mathrm{m})$ was used to separate PAHs. Helium was used as carrier gas with $1 \mathrm{ml} / \mathrm{min}$. FID temperature was held at $280^{\circ} \mathrm{C}$. Nitrogen was used as carrier and make-up gas for both analyses. Hydrogen and air were flame detector gases with $30 \mathrm{ml} / \mathrm{min}$ and 300 $\mathrm{ml} / \mathrm{min}$, respectively. EPA 525 Mixture was used for qualitative and quantitative of $\mathrm{PAH}$ analyses. Quantification of $\mathrm{PAH}$ was based on external standards $[10,11]$.

\section{RESULTS AND DISCUSSION}

In this study were analyzed water samples of Porto-Romano, consider as Hot-spot area in Albania. This area has been contaminated by human activity for more than 50 years due to elevated industrial activity in the past and now. Porto-Romano is located in the central part of Adriatic Sea, close to the city of Durres. Organochlorine pesticides were detected in all samples (Figure 2). Mean concentration of pesticides was $90.6 \pm 30.3 \mathrm{ug} / \mathrm{l}$. Many tones of pesticides were abandoned for several years in exchemical plants near Porto-Romano. This is the main factor for their presence in marine water. The highest concentration was found at station PRW2 for both periods. Average value for the total of pesticides was $209.4 \pm 37.2 \mathrm{ug} / \mathrm{l}$. This station is near the main channel that collects surface water from almost all the Porto-Romano area. Also, high levels were observed for the PRW8 $(132.5 \pm 17.5$ ug/l), PRW7 (113.2 $\pm 62.8 \mathrm{ug} / \mathrm{l})$ and PRW6 (101.2 $\pm 24.1 \mathrm{ug} / \mathrm{ll})$. These stations were located more in north of Porto-Romano. Their pollution may be consequence of marine currents in the Adriatic Sea and inside Porto Romano. Previous deposition of pesticides in sediments and their continuous emission into seawater column was not excluded. Minimum value of pesticides was found in PRW4 station $(27.16 \pm 11.9 \mathrm{ug} / \mathrm{l})$ that is located inside the hydrocarbon port. Found levels for other two stations (PRW3, PRW5) inside this port were relatively in low concentrations. Also, the station located on the most northern part (PRW9) was found in low concentrations due to the strong water currents. Note that pesticide values were depending obviously on the moment values as was shown by the differences between samples from the same station for both periods of sampling. Figure 3 shows the mean concentration of classes for organochlorine pesticide that were determined in water samples. Their profile was Endosulfanes > Aldrines > Heptachlores > Chlordanes > DDTs > $\mathrm{HCHs}$. The mean concentration of Endosulfanes (total of Endosulfan alpha, Endosulfan beta and Endosulfan sulfate isomer) was $43.2 \pm 12.3 \mathrm{ug} / \mathrm{l}$.

They were identified in all analyzed samples. Their presence must be result of recent use for agricultural purposes. PRW7 was the most polluted station (152.2 $\pm 45.2 \mathrm{ug} / \mathrm{l})$ with Endosulfanes. It was not excluded that Endosulfanes have not been used near Porto-Romano area (PRW2 at $41.2 \pm$ $6.6 \mathrm{ug} / \mathrm{l})$ but could be there due to marine currents in the Adriatic Sea. Aldrines (total of Aldrin, Dieldrin, Endrin, Endrin aldehyde, Endrin ketone) was the second group of pesticides found in high concentration. Average value of Aldrines was 14.9 $\pm 3.8 \mathrm{ug} / \mathrm{l}$. Degradation products of Aldrines (Endrin 
aldehyde and Endrin ketone) were found in higher concentration in all samples. Average levels for the total of Heptachlor and Heptachlor epoxides (cis and trans isomers) were $5.8 \pm 1.2 \mathrm{ug} / \mathrm{l}$. TranHeptachlor epoxide was found in higher level for all samples. Total of alpha and gamma-Chlordanes were $2.1 \pm 0.6 \mathrm{ug} / \mathrm{l}$. Aldrines, Heptachlores and Chlordanes are part of cyclopentadiene pesticides. These compounds were found in about $70 \%$ of analyzed samples. Their presence may be a consequence of their earlier uses. Note that, their residues (degradation products) were found in higher level compared to the primary compounds used as pesticides. This fact is related to previous uses of these pesticides, their degradation processes, and the persistence of each chemical individual. DDTs were found in $54 \%$ of water samples. Total of $p p^{\prime}-\mathrm{DDT}, p p^{\prime}-\mathrm{DDE}$ and $p p^{\prime}-\mathrm{DDD}$ were found in a mean value of $1.96 \pm 0.6 \mathrm{ug} / \mathrm{l}$. DDT was detected only in one sample (station PRW2, April 2019). DDE was found in higher concentration than DDD because of its stability. Presence of DDTs in the water of the Adriatic Sea was frequently reported because of its previous use in many countries and elevated persistence. Accumulations of DDT in sediment slow down its degradation process. Emission of DDTs and other pesticides from sediment could bring new arrival in the water column time to time. Also, water irrigation could be another source of pesticides and their residues in water of Adriatic Sea. Lindane and its isomers were found in lower level compare with other. Their average level was $1.8 \pm 0.6 \mathrm{ug} / \mathrm{l}$. It was expected that $\mathrm{HCH}$ concentration would be higher than other pesticides due to the discharge directly to the sea for large amounts of them for more than 30 years. Apparently these compounds degrade faster than other pesticides.

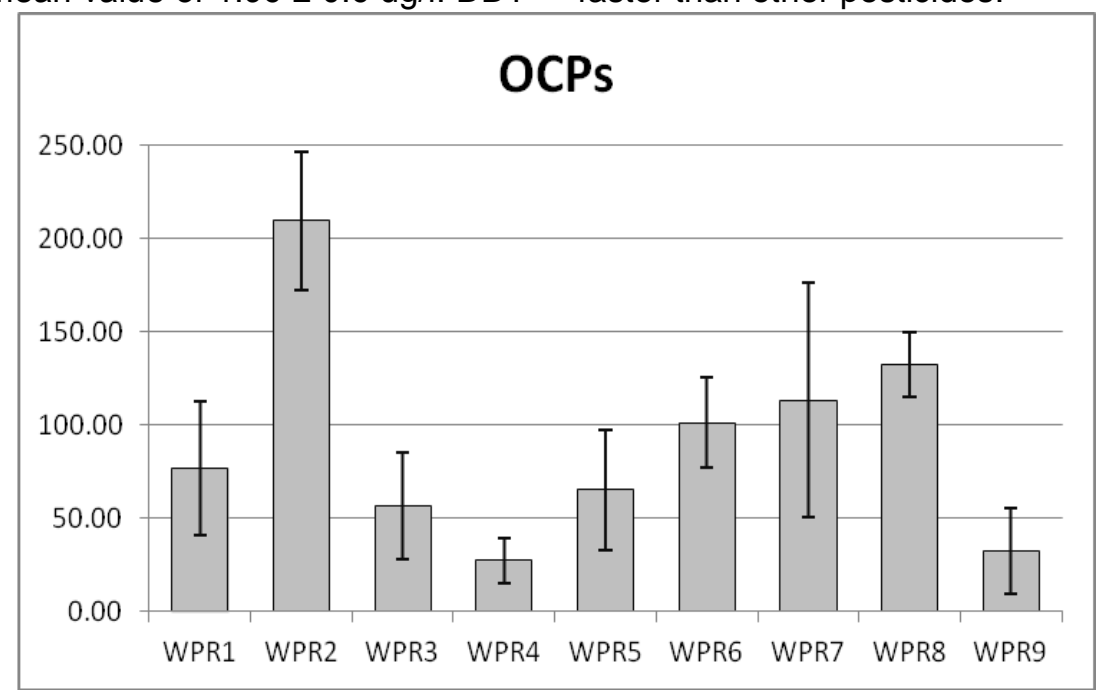

Figure 2. Total of organochlorine pesticides in water samples of Porto-Romano

Slika 2. Ukupna količina organohlornih pesticida u uzorcima vode Porto-Romana

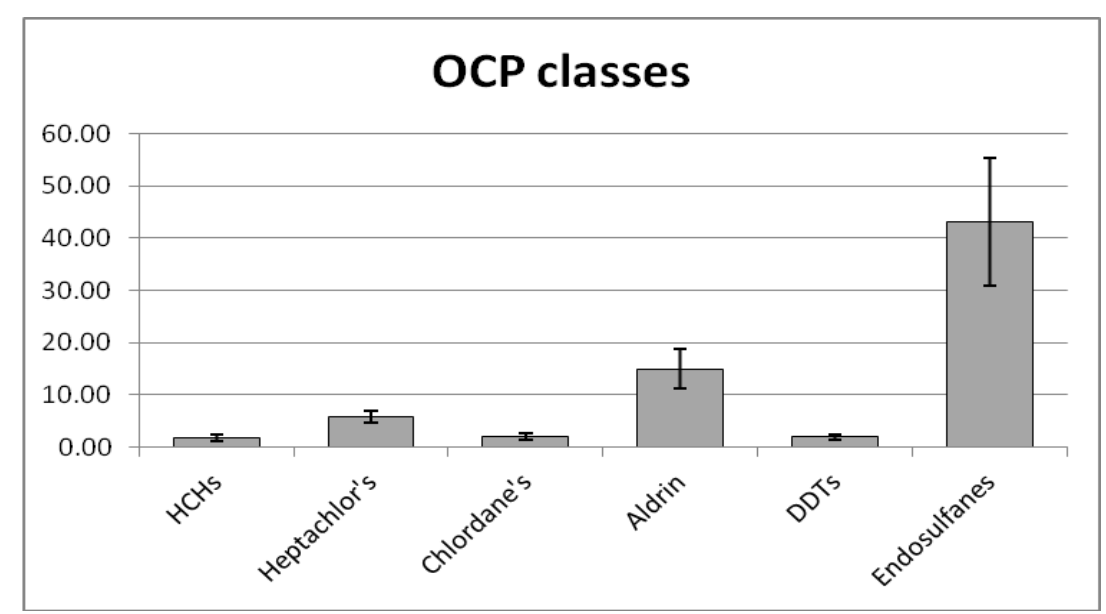

Figure 3. Classes of organochlorine pesticides in water samples of Porto-Romano

Slika 3. Klase organohlornih pesticida u uzorcima vode Porto-Romano 
Figure 4 shows the total of $\mathrm{PCB}$ markers in water samples of Porto-Romano. Mean concentration of PCB markers in water samples of December 2018 was $853.6 \mathrm{ug} / \mathrm{l}$ and in April 2019 the mean concentration was $256.9 \mathrm{ng} / \mathrm{g}$. PCB markers were found for all studied samples. Their presence could be because of atmospheric depositions or terrestrial sources. Discharging of wastes from some mechanical businesses near Porto-Romano could affect found level and their profile. Distribution of PCBs were the same for all samples except PCB 153 in PR5 station in
December 2018. This could be because the same pollution origin of $\mathrm{PCBs}$ in water samples of PortoRomano. PCB 153 and PCB 209 were found in higher level for both periods. Their source could be terrestrial. Also, volatile PCBs (PCB 28 and PCB 52) were found in higher level for all samples. This fact is connected with atmospheric origin of PCBs in this area. Profiles of PCBs were: PCB $153>$ PCB 209 > PCB 52 > PCB 28. The levels of PCBs in water samples of Porto-Romano were higher than reported levels for the previous studies[1] because of elevated industrial activity in this area.

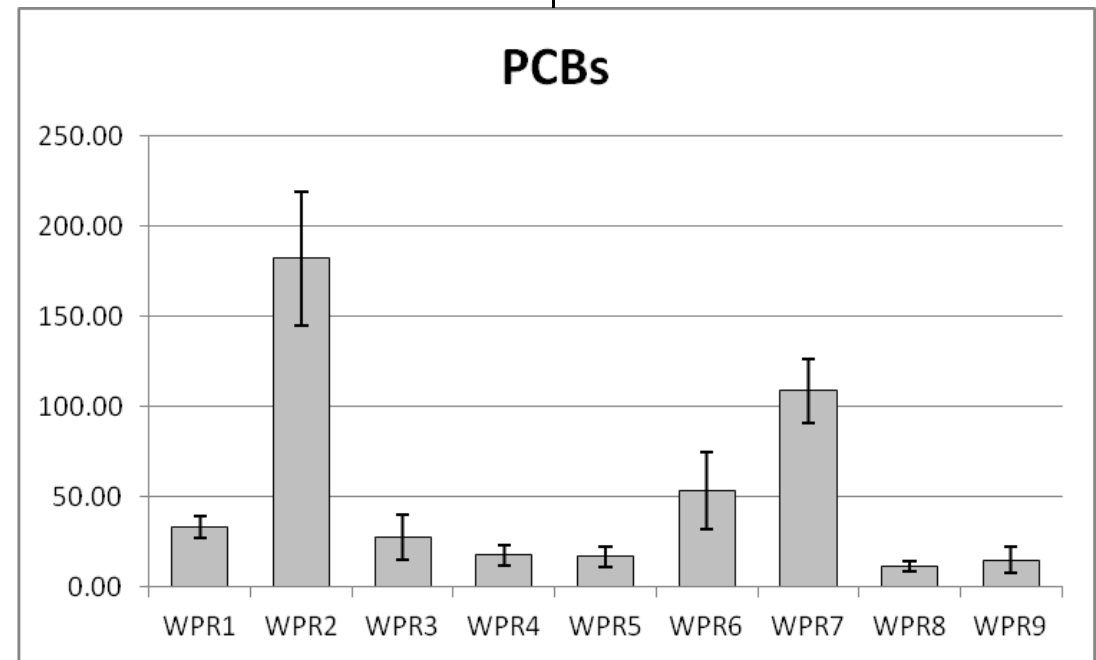

\begin{tabular}{|l|c|c|c|c|c|c|c|c|c|}
\hline \multicolumn{1}{|c|}{ PCB } & WPR1 & WPR2 & WPR3 & WPR4 & WPR5 & WPR6 & WPR7 & WPR8 & WPR9 \\
\hline Average & 33.23 & 182.02 & 27.71 & 17.66 & 16.86 & 53.51 & 108.77 & 11.69 & 14.96 \\
\hline STDV & 5.84 & 36.75 & 12.81 & 5.95 & 5.75 & 21.23 & 17.77 & 2.79 & 7.18 \\
\hline
\end{tabular}

Figure 4. PCB in water samples of Porto-Romano

Slika 4. PCB u uzorcima vode Porto-Romano

Figure 5 shown total of $13 \mathrm{PAHs}$ according EPA 525 Method in water samples of PortoRomano measured by GC/FID technique. Acenaphthylene, Fluorene, Phenanthrene, Anthracene, Pyrene, Benzo[a]anthracene, Chrysene, Perilene, Benzo[b]fluoranthene, Benzo[k]fluoranthrene, Indeo [1, 2, 3-cd]pyrene, Dibenzo[a,b]anthracene and Benzo[g,h,i]perylene were determined in water samples by using liquid-liquid exctraction followed by GC/FID technique. PAHs were detected for all studied samples. Mean concentration of $\mathrm{PAH}$ in analyzed water samples for both periods were 3.9 $\pm 1.5 \mathrm{mg} / \mathrm{l}$. PAHs were in higher concentration for PRW4 station with $7.6 \pm 2.1 \mathrm{mg} / \mathrm{l}$. PRW5 $(6.3 \pm 1.4$ $\mathrm{mg} / \mathrm{l})$ and PRW3 $(4.2 \pm 1.5 \mathrm{mg} / \mathrm{l})$, two other stations inside of hydrocarbon port, were found to be polluted by PAHs. Their presence could be because of elevated hydrocarbon activity in this Porto-Romano area. Terrestrial sources (fuel tanks), hydrocarbon activity (transferrin of fuels from ships to tanks and vice-versa) and ship transport could be the main pollution source of PAHs in marine water samples. It was shown the same distribution of PAHs all water samples because of the same pollution origin. Phenanthrene, Pyrene, Anthracene and Benzo[a]anthracene were most abundant peaks for all samples. The presence of some individual PAHs for PRW4 (Anthracene and Benzo[a]anthracene) and PRW5 (Fluorene, Pyrene and Benzo[a]anthracene) stations was noted. Also this could be a momentum value of PAHs depended on activities in this port in sampling periods. Car transport near the stations could be another factor. Main channel (PRW2 station) can bring PAHs from same mechanical businesses that discharge their wastes in it. Impact of ship transport in port of Durres can influence in elevated concentrations for 
PRW1 station $(5.3 \pm 2.8 \mathrm{mg} / \mathrm{l})$. PAH levels in water samples of Porto-Romano were higher than reported levels for other ecosystems of Albania
[11]. Presence of PAHs was higher because of hydrocarbon activity in this area.

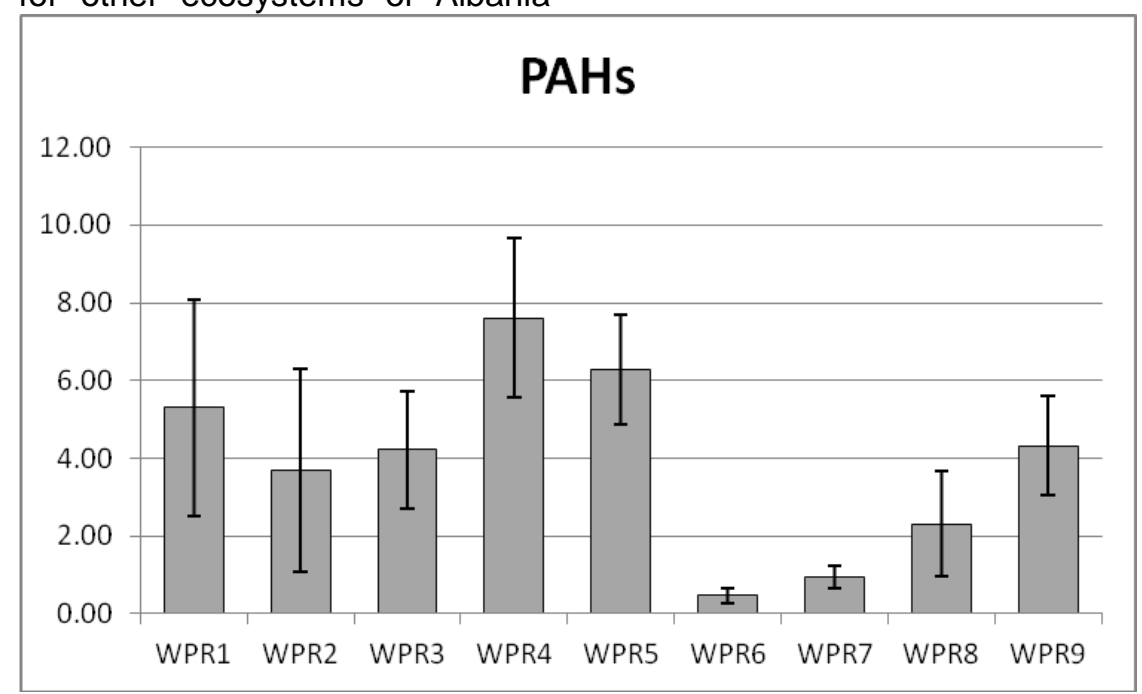

\begin{tabular}{|l|c|c|c|c|c|c|c|c|c|}
\hline \multicolumn{1}{|c|}{ PAH } & WPR1 & WPR2 & WPR3 & WPR4 & WPR5 & WPR6 & WPR7 & WPR8 & WPR9 \\
\hline Average & 5.31 & 3.69 & 4.21 & 7.60 & 6.28 & 0.47 & 0.94 & 2.31 & 4.33 \\
\hline STDV & 2.79 & 2.60 & 1.51 & 2.05 & 1.42 & 0.20 & 0.28 & 1.34 & 1.27 \\
\hline
\end{tabular}

Figure 5. PAH in water samples of Porto-Romano

\section{Slika 5. PAH u uzorcima vode Porto-Romana}

\section{CONCLUSIONS}

Determination of organochlorine pesticides, PCBs and PAHs was realized in water samples of Porto-Romano, Durres, Albania. GC/ECD technique was used for determination of organochlorine pesticides and PCBs. Qualitative and quantitative analyze of PAHs were realized by GC/FID technique. BTEX analyses in water samples were per-formed using HS/SME-FID technique. Organochlorine pesticides were found in higher level in sea water samples of Porto-Romano. OCP levels could be associated mainly with old pollution in this area from ex-chemical plant. Abandoning of pesticides for a long time near Porto-Romano is the main factor for their presence in this ecosystem. The higher concentration was in samples because of adsorption process. Distributions of organochlorine pesticides in water samples of PortoRomano were built by some individual pesticides. Organochlorine pesticide levels were lower or comparable than reported levels in other studies for Porto-Romano area. Presence of Dieldrin and Endosulfan alfa was higher because of new arrivals from terrestrial sources or use of these pesticides under false trademarks. PCB markers were found for all stations. Their presence could be mainly because of atmospheric depositions. Discharging of wastes from some mechanical businesses near study area could affect level and profile of PCBs.
PCB 28 was found in higher level in all samples. PCB 138 was found in high level in PR4 station. Levels of PCBs in water samples of Porto-Romano were lower than reported levels for the previous studies [1]. PAHs were found for all studied samples. Total of PAHs were in higher concentration in PR5 and PR6 stations. Their presence could be because of hydrocarbon activity and ship transport in Porto-Romano area. PAH levels in water samples of Porto-Romano were higher than reported levels in other ecosystem in Albania [11]. Analyze of organic pollutants in PortoRomano must be continued because of anthropogenic impact in this Hot-Spot area.

\section{REFERENCES}

[1] Xh.Borshi, A.Nuro, G.Macchiarelli, G.M.Palmerini (2016) Analyzes of Some Chlorinated Pesticides in Adriatic Sea. Case study: Porto-Romano, Durres, Albania, J. of Int. Envriomental Application and Sciences, 9(4), 521-424.

[2] E.Como, A.Nuro, B.Murtajn, E.Marku, A.Emiri (2013) Study of Some Organic Pollutants in Water Samples of Shkumbini River", Int. J. of Ecosystems and Ecology Sciences, 8(4), 573-579.

[3] A.Nuro, E.Marku, B.Murtaj (2018) Organochlorine pesticides and their residues in surface waters of Albania, Zastita Materijala, 59(4), 475 - 483. 
[4] I.K.Konstantinou, D.Hela, T.A.Albanis (2006) The status of pesticide pollution in surface waters (rivers and lakes) of Greece. Part I. Review on occurrence and levels, Environmental Pollution, 141(3), 555570 .

[5] A.Nuro, E.Marku, B.Murtaj (2017) Organic pollutants in water samples of Vjosa river - Albania, Zastita Materijala, 58 (3), 385 - 393.

[6] A.Nuro, E.Marku, M.Shehu (2012) Organochlorinated pesticide residues in marine water in the South of Albania, Int. J. of Ecosystems and Ecology Sciences, 2(1), 27-34.

[7] Z.Vryzas, G.Vassiliou, C.Alexoudis, E.Papadopoulou-Mourkidou (2009) Spatial and temporal distribution of pesticide residues in surface waters in northeastern Greece, Water Research, 43(1), 1-10.

[8] E.Marku, A.Nuro, B.Murtaj (2012) An analytical survey of PCB levels in sediment samples of Vlora
Bay, Albania, Natura Montenegrina, 10 (3), 275281.

[9] Th.Lekkas, G.Kolokythas, A.Nikolaou, M. Kostopoulou, A.Kotrikla, G.Gatidou, N.S.Thomaidis, S. Golfinopoulos, C.Makri (2004) Evaluation of the pollution of the surface waters of Greece from the priority compounds and other toxic compounds, Environment International, 30(8), 995-1007.

[10] E.Gustafson, M.Dickhut (1997) Distribution of polycyclic aromatic hydrocarbons in southern Chesapeake Bay surface water: evaluation of three methods for determining freely dissolved water concentrations, Environment Toxicology Chemistry, $16,452-461$.

[11] A.Nuro, E.Marku, B.Murtaj (2014) Determination of $\mathrm{PAH}$ and BTEX levels in water sampling using GC/FID technique. Case study: Patoku Lagoon, Int. J. of Ecosystems and Ecology Science, 4(2), 195200.

\title{
IZVOD
}

\section{NIVOI NEKIH ORGANSKIH ZAGAĐIVAČA U UZORCIMA VODE JADRANSKOG MORA. STUDIJA SLUČAJA: ŽARIŠTE PORTO-ROMANA, ALBANIJA}

U ovom radu su predstavljene koncentracije organohlornih pesticida (OCP), polihlorisanih bifenila $(P C B)$ i policikličnih aromatičnih ugljovodonika (PAH) u uzorcima morske vode područja PortoRomano. Porto-Romano se nalazi na obali Jadranskog mora, u blizini grada Drača, u centralnoj Albaniji. Smatralo se zagađenim područjem, jer je pre devedesetih godina bilo smešteno hemijsko postrojenje za proizvodnju lindana. Deponija u blizini Porto-Romana i povećana aktivnost za industrijski razvoj ovog područja mogu biti glavni izvori zagađenja vode poslednjih godina. Uzorci vode uzeti su u decembru 2018. i aprilu 2019. godine u devet stanica Porto-Romano. Ekstrakcija tečnost-tečnost korišćena je za izolovanje organskih zagađivača iz uzoraka vode. Postupak čišćenja hlorisanih zagađivača realizovan je u koloni Florisil. Kvalitativne i kvantitativne analize pesticida i PCB-a izvršene su u gasnom hromatografu HP 6890 Series II, opremljenom m-ECD detektorom. Za odvajanje zagađivača organohlora korišćena je kapilarna kolona Rtk-5. Analize $P A H$ realizovane su na Varian 450 GC, gasnom hromatografu opremljenom FID detektorom $i$ kapilarnom kolonom VF-1ms.

Najčešći organski zagađivači u uzorcima vode Porto-Romana bili su organohlorni pesticidi, zbog uticaja bivših hemijskih postrojenja na ovom području. Uorci materije Lindane i njegovi izomeri nisu pronađeni u visokoj koncentraciji. PCB 28, isparljivi srodnik, pronađen je u višim koncentracijama zbog svog atmosferskog porekla. Prisustvo PCB 138 pokazuje zemaljsko poreklo $P C B$-a u ovom području. PAH je pronađen u višim koncentracijama unutar luke. Njihova koncentracija bila je usled industrijske aktivnosti i brodskog transporta na ovom području. Loše upravljanje biljnim otpadom Lindane, gradsko zagađenje i nedavne industrijske aktivnosti faktori su kontinuiranog zagađenja na području Porto-Romano. Prisustvo organskih zagađivača u uzorcima vode Porto-Romana ukazuje na to da bi nadgledanje ovog žarišta trebalo biti kontinuirano.

KIjučne reči: Organohlorni pesticidi; PCB; PAH; zagađenje vode; GC / ECD / FID.

\author{
Naučni rad \\ Rad primljen: 08. 07. 2020. \\ Rad prihvaćen: 02. 08. 2020. \\ Rad je dostupan na sajtu: www.idk.org.rs/casopis
}

\footnotetext{
(c) 2020 Authors. Published by Engineering Society for Corrosion. This article is an open access article distributed under the terms and conditions of the Creative Commons Attribution 4.0 International license (https://creativecommons.org/licenses/by/4.0/)
} 